\title{
Endophytic culturable bacteria colonizing Lavandula dentata L. plants: isolation, characterization and evaluation of their plant growth-promoting activities
}

Pereira, S.I.A. ${ }^{1}$, Monteiro, C. ${ }^{1}$, Vega, A.L. ${ }^{1}$ and Castro, P.M.L. ${ }^{1 *}$

${ }^{1} \mathrm{CBQF}$ - Centro de Biotecnologia e Química Fina - Laboratório Associado, Escola Superior de Biotecnologia, Universidade Católica Portuguesa/Porto, Rua Arquiteto Lobão Vital, Apartado 2511, 4202-401 Porto, Portugal

*Corresponding author

Paula M. L. Castro

CBQF - Centro de Biotecnologia e Química Fina - Laboratório Associado, Escola Superior de Biotecnologia, Universidade Católica Portuguesa/Porto

Rua Arquiteto Lobão Vital, Apartado 2511, 4202-401 Porto, Portugal

E-mail: plcastro@porto.ucp.pt

Tel: +351225580067

Fax: + 351225090351 


\section{Abstract}

Aromatic plants such as lavender are stirring the attention of many researchers due to their content in bioactive secondary metabolites that can be used in traditional medicine. However, information regarding naturally occurring lavender associated bacterial endophytes (BE) is limited. To the best of our knowledge, this is the first study which aims to assess the phylogenetic diversity of the culturable endophytic bacteria of Lavandula dentata cultivated under organic management and to evaluate their potential as plant growth promoting (PGP) agents. BE were grouped by random amplified polymorphic DNA and identified by $16 \mathrm{~S}$ ribosomal RNA gene sequencing. Endophytes were further characterized for the ability to produce several PGP substances, like ammonia, siderophores, indol-3-acetic acid, hydrogen cyanide and for the ability to solubilize phosphate. Plant cell-wall degrading enzymes were also determined. Densities of BE were higher in roots ( $\log 6.39 \mathrm{CFU} \mathrm{g}^{-1}$ fresh weight) than in shoots (log 5.56 CFU g ${ }^{-1}$ fresh weight). Phylogenetic analysis showed that BE were affiliated to two major groups: $\gamma$-Proteobacteria (50\%) and Firmicutes $(31.6 \%)$ and a small part belonged to $\alpha$ - (7.9\%) and $\beta$-Proteobacteria (10.5\%), being Pseudomonas and Bacillus the most highly represented genera. Higher bacterial diversity was found in the lavender roots, with endophytes belonging to 6 different genera (Pseudomonas, Variovorax, Rhizobium, Caulobacter, Bacillus and Paenibacillus), than in shoots where only 3 genera (Bacillus, Pseudomonas and Xanthomonas) were found. Overall, BE showed ability to produce extracellular enzymes and multiple PGP traits, suggesting their potential use as efficient bioinoculants in sustainable cultivation of medicinal and aromatic plants.

\section{Keywords}

Endophytic bacteria; diversity; indol-3-acetic acid; lavender; plant growth promotion 


\section{Introduction}

Lavandula species (Lamiaceae) are endemic to the Mediterranean region, Arabian Peninsula, Canary Islands, and India (Upson, 2002), being widely cultivated worldwide, due to their economic value for cosmetic and pharmaceutical industries and also for ornamental purpose (Bakkali et al., 2008; Muyima et al., 2002). Bioactive secondary metabolites such as essential oils are extracted from various aromatic plants and in particular those extracted from Lavandula dentata stand out for their use in popular medicine as antidiabetic, antihypertensive, and antiprotozoal agent (Al-Musayeib et al., 2012), explaining the growing interest of the pharmaceutical industries in these natural compounds.

Lavender species can be propagated by seeds or by woody stem cuttings. The propagation through seeds is usually slow, plants show a large variation in growth and in oil composition, and the genetic uniformity of the resulting plants is not guaranteed (Zuzarte et al., 2010). For these reasons, vegetative propagation is preferred to reproduction by seeds. Propagation by cuttings is fast, does not require special techniques and methods and is less expensive than in vitro micropropagation (Zuzarte et al., 2010). However, the poor rooting capacity of cuttings is often observed. In order to overcome this problem, plant growth regulators like the indole-3-butyric acid (IBA) and indole-3-acetic acid (IAA) are commonly used and showed to be efficient in increasing the adventitious root formation and the rooting capacity of cuttings (Bona et al., 2010; Kasem and El-baset, 2014). However, chemical application raises environmental concerns and increase production costs thus the use of sustainable practices in the production of medicinal and aromatic plants is imperative.

Plant growth promoting rhizobacteria (PGPR) have been used as bioinoculants for improving plant growth in a wide range of environments and crop species (Pereira and Castro, 2014a; Pereira et al., 2015). Several authors also reported that PGPR induced root formation in stem cuttings of several aromatic plants, namely in Mentha piperita (Kaymak et al., 2008) 
and in L. angustifolia (Kasem and El-baset, 2014). However, very little is known about the effects of bacterial endophytes (BE) on the rooting capacity of cuttings.

Endophytic bacteria are defined as those that colonize the inner tissues of healthy plants without causing symptoms of disease or detrimental effect on their host (Schulz and Boyle, 2006). Similarly to rhizobacteria, BE promote plant growth by several mechanisms, including phosphate solubilization, nitrogen fixation, production of siderophores and ammonia and through the production of wide range of phytohormones, such as auxins, cytokinins and gibberellic acids (Pereira and Castro, 2014b; Verma et al., 2001). Endophytic bacteria have the advantage of proliferating within the plant tissue thus facing less competition for nutrients and being protected from high-stress environment of the soil (Sturz et al., 2000). Endophytes have been isolated from a wide range of plant species and tissues suggesting their ubiquitous existence in higher plants. However, only a few of all the plants existing on earth have ever been studied relative to their bacterial endophytic pool (Strobel and Daisy, 2003), increasing the probability to find new and beneficial endophytes with potential to be applied in biotechnology. The microbiome of medicinal and aromatic plants is extremely important since there is increasing evidences that the spectrum of bioactive metabolites may be related to the activity of associated BE (Emiliani et al., 2014). However, little attention has been paid to the BE from aromatic and medicinal plants and there is a lack of reports in this research area.

The aim of the present study was to isolate and characterize BE from tissues (root and shoot) of $L$. dentata plants growing under organic management. We further intended to assess the phylogenetic diversity and the phenotypic characterization of the culturable BE; and to evaluate their ability to produce plant growth promoting (PGP) substances, such as IAA, ammonia, hydrogen cyanide (HCN), siderophores and extracellular enzymes (lipases, cellulases, proteases, pectinases) and to solubilize phosphate, in order to indicate BE with 
potential to be used as bioinoculants in vegetative propagation of aromatic and medicinal plants.

\section{Material and Methods}

\subsection{Enumeration and isolation of cultivable bacterial endophytes}

To isolate representative BE four healthy Lavandula dentata L. plants grown under organic management were collected at random from the "Cantinho das Aromáticas" located in

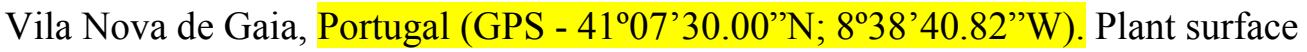
sterilization was performed according to Pereira and Castro (2014b). The success of the surface disinfection process was evaluated by plating $100 \mu \mathrm{l}$ of water from the final rinse on Trypticase Soy Agar (TSA; Pronadisa) agar medium and incubated at $30^{\circ} \mathrm{C}$ for 3 days. No bacterial growth was found.

For bacterial enumeration $1 \mathrm{~g}$ of roots and shoots were homogenized in $9 \mathrm{ml}$ of sterile phosphate buffered saline (PBS g ${ }^{-1}: \mathrm{Na}_{2} \mathrm{HPO}_{4}, 1.44 ; \mathrm{KH}_{2} \mathrm{PO}_{4}, 0.24 ; \mathrm{KCl}, 0.20 ; \mathrm{NaCl}, 8.00$; $\mathrm{pH}$ 7.4). Serial dilutions were made in duplicate and $0.1 \mathrm{ml}$ of each dilution was spread onto TSA and Plate Count Agar (PCA; Merck) media. Plates were incubated for 7 days at $30{ }^{\circ} \mathrm{C}$ and the number of colony forming units (CFU) determined. Different bacterial colonies were isolated based on size, morphology and color, from TSA and PCA media, using a streak-plate procedure. Isolates were purified and further phenotypically characterized.

\subsection{Random Amplified Polymorphic DNA (RAPD) and DNA sequencing analysis}

Bacterial isolates were grouped according to species similarity, based on RAPD profiles produced with primer M13 (5'GAGGGTGGCGGTTCT-3'). DNA extraction and RAPD analysis were performed according to the methods described in Pereira and Castro (2014b). RAPD amplification products were run on a 1.5\% agarose gel stained with SYBR 
Safe (Invitrogen, UK) for $135 \mathrm{~min}$ at $80 \mathrm{~V}$. RAPD patterns were compared using Bionumerics software (Applied Maths, St-Martens-Laten, Belgium) and clustered according to their similarities. Isolates displaying unique RAPD profiles were subsequently identified by $16 \mathrm{~S}$ rRNA gene sequencing analysis. 16S rDNA amplification was performed with universal primers, 27F and 1492R as previously described by Pereira and Castro (2014b). The PCR

products were purified using a GRS PCR \& Gel Band Purification Kit (Grisp) and sequencing was performed by Macrogen Inc. (Netherlands). Sequence editing and inspection were performed using BioEdit program 7.0 version and the sequence similarity search was performed using the EzTaxon sever. For phylogenetic analyses, the sequences were aligned by using the CLUSTALW (Thompson et al., 1994). Tree constructions were performed with MEGA 5.0, using the neighbour-joining method (Kimura two-parameter distance optimized criteria). The robustness of the phylogenetic tree was confirmed by using bootstrap analysis based on 1000 resamplings of the sequences. The 16S rRNA sequences of the BE were deposited in GenBank database under accession numbers KP407086 to KP407123. Simpson's (1-D) and Shannon's (H) diversity indices were calculated based on the percentage of different bacterial genera in both plant compartments.

\subsection{Plant growth promotion (PGP) traits}

The amount of IAA produced by BE was determined according to Gordon and Weber (1951). Briefly, an aliquot of $500 \mu \mathrm{l}$ of supernatant obtained from bacterial cultures grown in the presence of L-tryptophan (1\%) was mixed with $350 \mu$ of Salper reagent. The absorbance of pink colour developed after $30 \mathrm{~min}$ of incubation in dark was read at $530 \mathrm{~nm}$. The IAA concentration was determined using a calibration curve of pure IAA as a standard. Detection of siderophore production was carried out by inoculating the BE on Chrome Azurol S medium (Schwyn and Neilands, 1987). The development of a yellow to orange halo around 
the colonies after incubation at $30^{\circ} \mathrm{C}$ for $72 \mathrm{~h}$ indicated a positive result for siderophore production. The detection of $\mathrm{HCN}$ production was made by amending nutrient agar with $4.4 \mathrm{~g}$ glycine $\mathrm{l}^{-1}$ and streaking the isolates on this modified agar plates. On the top of each plate, a sterilized filter paper (Whatman No.1) soaked in $2 \%$ sodium carbonate prepared in $0.5 \%$ picric acid solution was placed. Plates were incubated at $30^{\circ} \mathrm{C}$ for 4 days after which development of orange to red color indicated HCN production (Ahmad et al., 2008). For assessing the ability to produce ammonia, fresh cultures were inoculated into $10 \mathrm{ml}$ of peptone water and incubated at $30{ }^{\circ} \mathrm{C}$ for $48 \mathrm{~h}$; following this, $0.5 \mathrm{ml}$ of Nessler's reagent (Sigma-Aldrich) were added to each tube and development of yellow to brown color was considered as a positive result for ammonia production (Cappuccino and Sherman, 1992). For phosphate solubilisation assay, fresh cultures were inoculated into National Botanical Research Institute Phosphate (NBRIP) medium supplemented with $0.5 \%$ tricalcium phosphate (Nautiyal, 1999). The presence of a clearing halo around bacterial colonies were considered positive for phosphate solubilization.

Bacterial endophytes were screening for their ability to produce extracellular enzymes (proteases, cellulase, pectinase and lipases) according to the methods described in Pereira and Castro (2014b).

\section{Results and Discussion}

In the last years, several studies have focused their attention on aromatic and medicinal plants due to the presence of distinct bioactive secondary metabolites that can be used in traditional medicine. Despite the great interest in medicinal plants, very little is known about the associated BE. To the best of our knowledge, this work is the first to assess the phylogenetic diversity of the culturable endophytic bacterial populations of $L$. dentata plants cultivated under organic management and to evaluate their plant growth promoting traits. 
In this study, the number of endophytic culturable bacteria varied significantly among plant organs. The colony forming units in roots varied between $\log 6.21 \mathrm{CFU} \mathrm{g}^{-1}$ fresh weight (FW) (for TSA medium) and $\log 6.39 \mathrm{CFU} \mathrm{g}^{-1} \mathrm{FW}$ (for PCA medium) and were higher if compared to shoot where bacterial counts ranged from $\log 5.31 \mathrm{CFU} \mathrm{g}^{-1} \mathrm{FW}$ (for TSA) to $\log$ 5.56 CFU g ${ }^{-1} \mathrm{FW}$ (for PCA). Similar results were obtained for Echinacea purpurea and Echinacea angustifolia where the lowest bacterial counts were determined in the aboveground tissues, while the highest bacterial numbers were detected in roots (Chiellini et al., 2014). A similar trend was observed by Aravind et al. (2009) in black pepper (Piper nigrum) plants. However, several authors reported that population density of endophytes in aromatic and medicinal plants seem to be highest in aerial than in the belowground tissues. Emiliani et al. (2014) and El-Deeb et al. (2013) showed that leaves had higher numbers of endophytic bacteria than roots in Lavandula angustifolia and Plectranthus tenuiflorus plants, respectively.

Based on the distinct colony characteristics a total of $56 \mathrm{BE}$ were isolated from the plant tissues of $L$. dentata plants growing under organic management. However, according to RAPD analysis only 38 different profiles were recognised, corresponding to 27 bacterial strains from roots (LR) and 11 strains from shoots (LS) (Table 1). The higher numbers of bacterial counts found in lavender roots, as well as the higher number of endophytes recovered from this tissue, may reflect the intimate contact of roots with soil rhizosphere, which facilitate the entry of bacteria into the root tissues (Kobayashi and Palumbo, 2000). In addition, the endophytic bacterial population densities reported in the present study were higher than the earlier reports in aromatic and medicinal plants such as P. nigrum (Aravind et al., 2009) and L. angustifolia (Emiliani et al., 2014). These results may be related to the management practices used for the cultivation of lavender plants, since organic management 
seems to promote microbial activity in rhizosphere (Reilly et al., 2013), increasing the bacterial pool that can enter into plant tissues.

One isolate of each cluster was chosen for 16S rRNA partial gene sequence (Fig. 1). As shown in Table 1, all BE showed high similarities (98-100\%) with their closest related species. Phylogenetic analyses based on 16S rRNA gene sequences showed that BE isolated from lavender tissues belonged to two main groups: $\gamma$-Proteobacteria $(50 \%)$ and Firmicutes (31.6\%), being a small portion affiliated to $\alpha$-Proteobacteria $(7.9 \%)$ and $\beta$-Proteobacteria (10.5\%). Overall, BE belonged to 7 different genera, being Pseudomonas (47\%) and Bacillus $(29 \%)$ the better represented in lavender plants (Table 1). A similar trend was already described by several authors for other aromatic and medicinal plants. Emiliani et al. (2014) reported that $51 \%$ of the $\mathrm{BE}$ isolated from L. angustifolia tissues belonged to Pseudomonas genus, while Vendan et al. (2010) showed a predominance of the genus Bacillus in ginseng plants. In fact, both genera have been identified as frequently occurring endophytes in several plant species (Hallmann and Berg, 2006).

The results also showed that BE colonized differently lavender tissues. In roots, where higher bacterial diversity was found, endophytes belonged to 6 different genera (Pseudomonas, Variovorax, Rhizobium, Caulobacter, Bacillus and Paenibacillus), while in shoots $91 \%$ of the endophytic isolates were affiliated to Bacillus and Pseudomonas and only one isolate belonged to Xanthomonas genus. Some of these genera have already been described in other aromatic and/or medicinal plants. Cho et al. (2007) isolated 63 different endophytic strains belonging to 13 different genera including Bacillus and Paenibacillus from the interior of ginseng tissues. Emiliani et al. (2014) also isolated endophytes affiliated to Rhizobium, Pseudomonas, Bacillus genera from L. angustifolia plants. However, to the best of our knowledge BE belonging to Caulobacter and Variovorax genera were never detected in lavender plant compartments. The differences among the culturable bacterial populations in 
both lavender organs were also highlighted by the diversity indices calculated based on genera distribution, since Simpson's and Shannon's indices were higher in roots $(D=0.74$ and $\mathrm{H}=1.45$, respectively) if compared to shoots $(\mathrm{D}=0.56$ and $\mathrm{H}=0.86$, respectively).

The distribution of BE in roots and shoots of $L$. dentata plants may be related to the distinct anatomical and nutritional conditions found in both plant compartments, leading to the creation of specific ecological niches for endophytic growth. According to Gaiero et al. (2013) endophyte distribution within plants depends on a combination of skills to colonize and the allocation of plant resources. In addition, according to Compant et al. (2010) the secretion of cell-wall degrading enzymes by endophytes is an important trait for tissue colonization and bacterial spreading inside plants. In this study, the production of extracellular enzymes such as cellulases, pectinases, proteases and lipases by BE was assessed and the results are shown in Table 2. Bacterial endophytes had higher ability to produce pectinases (68\%) and proteases (79\%) than cellulases (50\%) and lipases (58\%). In general, endophytic bacteria from shoots showed higher ability to produce plant cell wall-degrading enzymes, especially pectinases and proteases, suggesting that endophytic colonization of shoots may be closely related to BE capacity to produce extracellular enzymes. Verma et al. (2001) also reported cellulase and pectinase activities in different isolates suggesting their potential for inter- and intracellular colonization.

Rooting of stem cutting is widely used in horticulture for the propagation of aromatic and medicinal plants, however poor rooting is often observed (Kasem and El-baset, 2014). In order to overcome this problem synthetic auxins are often applied at stimulating the adventitious root formation on cuttings (Bona et al., 2010), however due to the continuous increase of environmental footprint it is urgent to find eco-friendly alternatives. Although several studies have reported the beneficial effect of BE and PGPR inoculation in several 
economically-important crops, like maize (Pereira and Castro, 2014a), carrot and potatoes (Surette et al., 2003), little information is available for aromatic and medicinal plants.

Screening results of PGP traits of the lavender BE are shown in Table 2. All endophytic strains were able to synthesize IAA in the presence of the precursor L-tryptophan, with levels ranging from 7.0 to $74.7 \mathrm{mg} \mathrm{l}^{-1}$. Several BE (21\%) produced more than $40 \mathrm{mg}^{-1}$ of IAA and most of them were affiliated to Pseudomonas genus. Bacterial endophytes isolated from ginseng plants also showed ability to synthetize IAA even though at lower levels (Vendan et al., 2010). The application of PGPR in order to minimize the use of synthetic auxins was already reported by Kasem and El-baset (2014) and Kaymak et al. (2008) who showed that the inoculation of PGPR in L. dentata cuttings and M. piperina, respectively improved rooting performance. However, so far no studies are available concerning the PGP of BE isolated from aromatic and medicinal plants and their ability to increase stem cutting establishment in soils. Additionally to auxin production, all endophytic strains were able to produce ammonia and siderophores. According to Idris et al. (2004) siderophore production among endophytes may be a general phenotype, since endophytes have to compete with plant cells for Fe supply. Several BE also showed ability to solubilize phosphate, which is of great importance to enhance $\mathrm{P}$ availability in soils during the initial colonization.

In this work, several potential human pathogens were isolated from lavender tissues, namely the strains LR 1-11, LR 2-1, LR 2-4, LR 2-6, LR 3-3, LR 3-7, LS 1-4 and LS 3-1 that are members of the Bacillus cereus group of bacteria. These BE were found in both plant organs, but with higher incidence in roots. This is an issue of concern, since many genera including Burkholderia, Enterobacter, Bacillus and Stenotrophomonas have been identified as colonizers of the plant rhizosphere but some members can also successfully colonize human organs and tissues causing diseases (Berg et al., 2005). Consequently, the selection of 
bacterial endophytes to be applied as bioinoculants in plant cultures should take in consideration the risk of pathogenicity to ensure that they do not inadvertently pose a threat to human health.

\section{Conclusions}

Bacterial endophytes seem to colonize differently lavender tissues. Beyond the higher numbers of BE found in the roots, phylogenetic analysis also showed clear differences between plant organs. In roots, a high diversity of genera was observed and BE were affiliated to Pseudomonas, Variovorax, Rhizobium, Caulobacter, Bacillus and Paenibacillus, while in shoots isolates belonged to Bacillus, Pseudomonas and Xanthomonas genera. The BE isolated in this study showed several plant growth promoting traits which suggest their potential for plant growth promotion. The use of such BE as efficient bioinoculants may constitute an interesting alternative to the application of chemical compounds, for sustainable cultivation of medicinal and aromatic plants.

\section{Acknowledgments}

This work was supported by National Funds through FCT - Fundação para a Ciência e a Tecnologia under the project PTDC/AGR/CFL/111583/2009, project PEst-

OE/EQB/LA0016/2011 and Fundo Social Europeu (III Quadro Comunitário de Apoio). Sofia Pereira and Cristina Monteiro had the support of FCT grants SFRH/BPD/65134/2009 and SFRH/BPD/80885/2011, respectively. 


\section{References}

Ahmad, F., Ahmad, I., Khan, M.S., 2008. Screening of free-living rhizospheric bacteria for their multiple plant growth promoting activities. Microbiol. Res. 163, 173-181

Al-Musayeib, N.M., Mothana, R.A., Matheeussen, A., Cos, P., Maes, L., 2012. In vitro antiplasmodial, antileishmanial and antitrypanosomal activities of selected medicinal plants used in the traditional Arabian Peninsular region. BMC Complem. Altern. Med. 12, 49-55

Aravind, R., Kumar, A., Eapen, S.J., Ramana, K.V., 2008. Endophytic bacterial flora in root and stem tissues of black pepper (Piper nigrum L.) genotype: isolation, identification and evaluation against Phytophora capsici. Lett. Appl. Microbiol. 48, 58-64

Bakkali, F., Averbeck, S., Averbeck, D., Idaomar, M., 2008. Biological effects of essential oils - A review. Food Chem. Toxicol. 46, 446-475

Berg, G., Eberl, L., Hartmann, A., 2005. The rhizosphere as a reservoir for opportunistic human pathogenic bacteria. Environ. Microbiol. 7, 1673-1685

Bona, C.M., Biasi, L.A., Lipski, B., Masetto, M.A.M., Deschamps, C., 2010. Adventitious rooting of auxin-treated Lavandula dentata cuttings. Ciência Rural. 40, 1210-1213

Cappuccino, J.C., Sherman, N., 1992. Microbiology: A Laboratory Manual (third ed), Benjamin/Cummings Pub. Co., New York, pp. 125-179

Chiellini, C., Maida, I., Emiliani, G., Mengoni, A. Mocali, S., Fabiani, A., Biffi, S., Maggini, V., Gori, L., Vannacci, A., Gallo, E., Firenzuoli, F., Fani, R., 2014. Endophytic and rhizospheric bacterial communities isolated from the medicinal plants Echinacea purpurea and Echinacea angustifolia. Int. Microbiol. 17, 165-174 
Cho, K.M., Hong, S.Y., Lee, S.M., Kim, Y.H., Kahng, G.G., Lim, Y.P., Kim, H., Yun, H.D., 2007. Endophytic bacterial communities in ginseng and their antifungal activity against pathogens. Microbial Ecol. 54, 341-351

Compant, S., Clément, C., Sessitsch, A., 2010. Plant growth-promoting bacteria in the rhizoand endosphere of plants: Their role, colonization, mechanisms involved and prospects for utilization. Soil Biol. Biochem. 42, 669-678

El-Deeb, B., Fayez, K., Gherbawy, Y., 2013. Isolation and characterization of endophytic bacteria from Plectranthus tenuiflorus medicinal plant in Arabia desert and their antimicrobial activities. J. Plant Interact. 8, 56-64

Emiliani, G., Mengoni, A., Maida, I., Perrin, E., Chiellini, C., Fondi, M., Gallo, E., Gori, L., Maggini, V., Vannaci, A., Biffi, S., Firenzuoli, F., Fani, R., 2014. Linking bacterial endophytic communities to essential oils: clues from Lavandula angustifolia Mill. Evid-Based Compl. Alt. Med. 2014, 1-16.

Gaiero, J.R., Mccall, C.A., Thompson, K.A., Day, N.J., Best, A.S., Dunfield, K.E., 2013. Inside the root microbiome: bacterial root endophytes and plant growth promotion. Am. J. Bot. $100,1738-1750$

Gordon, S.A., Weber, R.P., 1951. Colorimetric estimation of indoleacetic acid. Plant Physiol. $26,192-195$

Hallmann, J, Berg, G., 2006. Spectrum and population dynamics of bacterial root endophytes, in: Schulz, B., Boyle, C., Sieber, T.N. (Eds.), Microbial Root Endophytes. Springer-Verlag, Berlin, pp. 15-31 
Idris, R., Trifonova, R., Puschenreiter, M., Wenzel, W.W., Sessitsch, A., 2004. Bacterial communities associated with flowering plants of the Ni hyperaccumulator Thlaspi goesingense. Appl. Environ. Microbiol. 70, 2667-2677

Kaymak, H.C., Yarali, F., Guvenc, I., Donmez, M.F., 2008. The effect of inoculation with plant growth rhizobacteria (PGPR) on root formation of mint (Mentha piperita L.) cuttings. African J. Biotechnol. 7, 4479-4483.

Kasem, M.M., El-baset, M.M.A., 2014. A comparative study to improve rooting of English lavender stem cuttings. Afr. J. Agr. Res. 9, 3632-3637.

Kobayashi, D.Y., Palumbo, J.D., 2000. Bacterial endophytes and their effects on plants and uses in agriculture, in: Bacon, C.W., White, J.F. (Eds.), Microbial endophytes. Marcel Dekker Inc., New York, pp. 199-233

Muyima, N.Y.O., Zulu, G., Bhengu, T., Popplewell, D., 2002. The potential application of some novel essential oils as natural cosmetic preservatives in an aqueous cream formulation. Flavour Fragr. J. 17, 258-266

Nautiyal, V., 1999. An efficient microbiological growth medium for screening phosphate solubilizing microorganisms. Microbiol. Lett. 170, 265-270

Pereira, S.I.A., Castro, P.M.L., 2014a. Phosphate-solubilizing rhizobacteria enhance Zea mays growth in agricultural P-deficient soils. Ecol. Eng. 73, 526-535

Pereira, S.I.A., Castro, P.M.L., 2014b. Diversity and characterization of culturable bacterial endophytes from Zea mays and their potential as plant growth-promoting agents in metaldegraded soils. Environ. Sci. Pollut. R. 21, 14110-14123 
Pereira, S.I.A., Barbosa, L.V., Castro, P.M.L., 2015. Rhizobacteria isolated from a metal polluted area enhance plant growth in zinc and cadmium contaminated soil. Inter. J. Environ. Sci. Technol. 12, 2127-2142.

Reilly, K., Cullen, E., Lola-Luz, T., Stone, D., Valverde, J., Gaffney, M., Brunton, N., Grant, J., Griffiths, B.S., 2013. Effect of organic, conventional and mixed cultivation practices on soil microbial community structure and nematode abundance in a cultivated onion crop. J. Sci. Food Agric. 93, 3700-3709

Schulz, B., Boyle. C., 2006. What are Endophytes?, in: Schulz, B., Boyle, C., Sieber, T.N. (Eds.), Microbial Root Endophytes. Springer-Verlag, Berlin, pp. 1-13

Schwy, B., Neilands, J.B., 1987. Universal chemical assay for the detection and determination of siderophores. Anal. Biochem. 160, 47-56

Strobel, G., Daisy, B., 2003. Bioprospecting for microbial endophytes and their natural products. Microbiol. Mol. Biol. R. 67, 491-502

Sturz, A.V., Christie, B.R., Nowak, J., 2000. Bacterial endophytes: potential role in developing sustainable systems of crop production. Crit. Rev. Plant Sci. 19, 1-30

Surette, M.A., Sturz, A.V., Lada, R.R., Nowak, J., 2003. Bacterial endophytes in processing carrots (Daucus carota L. var. sativus): their localization, population density, biodiversity and their effects on plant growth. Plant Soil. 253, 381-390

Thompson, J.D., Higgins, D.G., Gibson, T.J., 1994. CLUSTALW: improving the sensitivity of progressive multiple sequence alignment through sequence weighting, position-specific gap penalties and weight matrix choice. Nucleic Acids Res. 22, 4673-4680 
Vendan, R.T., Yu, Y.J., Lee, S.H., Rhee, Y.H., 2010. Diversity of endophytic bacteria in ginseng and their potential for plant growth promotion. J. Microbiol. 48, 559-565

Verma, S.C., Ladha, J.K., Tripathi, A.K., 2001. Evaluation of plant growth promoting and colonization ability of endophytic diazotrophs from deep water rice. J. Biotechnol. 91, $127-$ 141

Upson, T., 2002. The taxonomy of genus Lavandula, Taylor and Francis, London

Zuzarte, M.R., Dinisa, A.M., Cavaleiro, C., Salgueiro, L.R., Canhoto, J.M., 2010. Trichomes, essential oils and in vitro propagation of Lavandula pedunculata (Lamiaceae). Ind. Crop.

Prod. 32, 580-587 


\section{Figure Captions}

Fig. 1. Neighbour-joining phylogenetic tree based on partial 16S rRNA sequences, showing the relationships between sequences of representative strains of bacterial endophytes and some of their closest phylogenetic relatives. Bootstrap values are shown at nodes. Acidilobus saccharovorans (NR115208.1) was used as outgroup. Bar indicates 0.05 substitutions per nucleotide position 
Table 1 - Phylogenetic affiliation to the closest relative and characterization of bacterial endophytes isolated from Lavandula dentata $\mathrm{L}$.

\begin{tabular}{|c|c|c|c|c|c|c|c|c|c|}
\hline Strain & $\begin{array}{l}\text { NCBI acession } \\
\text { No. }\end{array}$ & Phylogenetic affiliation & Closest EzTaxon-e match (acession number) & $\begin{array}{l}\text { Similarity } \\
(\%)\end{array}$ & $\begin{array}{l}\text { Gram } \\
\text { reaction }\end{array}$ & $\begin{array}{l}\text { Colony } \\
\text { pigmentation }\end{array}$ & $\begin{array}{l}\text { Cell } \\
\text { morphology }\end{array}$ & Catalase & Oxidase \\
\hline LR 1-1 & KP407086 & $\gamma$-Proteobacteria & Pseudomonas brassicacearum subsp neoaurantiaca ATCC 49054 (EU391388) & 100 & - & bege & Rod & + & + \\
\hline LR 1-2 & KP407087 & $\alpha$-Proteobacteria & Rhizobium nepotum 39/7 (FR870231) & 100 & - & bege & Rod & - & + \\
\hline LR 1-5 & KP407088 & $\gamma$-Proteobacteria & Pseudomonas moorei RW10T (AM293566) & 100 & - & bege & Rod & + & + \\
\hline LR 1-6B & KP407089 & $\beta$-Proteobacteria & Variovorax boronicumulans BAM-48 (AB300597) & 100 & - & yellow & Rod & + & + \\
\hline LR 1-7 & KP407090 & $\beta$-Proteobacteria & Variovorax soli GH9-3 (DQ432053) & 98 & - & bege & Rod & + & + \\
\hline LR 1-9 & KP407091 & $\gamma$-Proteobacteria & Pseudomonas graminis DSM $11363(\mathrm{Y} 11150)$ & 99 & - & bege & Rod & + & + \\
\hline LR 1-11 & KP407092 & Firmicutes & Bacillus cereus biovar toyoi CNCM I-1012 (AJ310100) & 100 & + & bege & Rod & + & + \\
\hline LR 1-12 & KP407093 & $\alpha$-Proteobacteria & Caulobacter vibrioides CB51 (AJ009957) & 100 & - & bege & Rod & + & + \\
\hline LR 1-13 & KP407094 & $\beta$-Proteobacteria & Variovorax boronicumulans BAM-48 (AB300597) & 100 & - & yellow & Rod & + & + \\
\hline LR 1-16 & KP407095 & $\gamma$-Proteobacteria & Pseudomonas brassicacearum subsp neoaurantiaca CIP 109457 (EU391388) & 100 & - & bege & Rod & + & + \\
\hline LR 2-1 & KP407096 & Firmicutes & Bacillus thuringiensis IAM 12077 (D16281) & 100 & + & bege & Rod & + & - \\
\hline LR 2-2 & KP407097 & $\gamma$-Proteobacteria & Pseudomonas kilonensis 520-20 (AJ292426) & 100 & - & bege & Rod & + & + \\
\hline LR 2-3 & KP407098 & $\gamma$-Proteobacteria & Pseudomonas jessenii CIP 105274 (AF068259) & 99 & - & yellow & Rod & + & + \\
\hline LR 2-4 & KP407099 & Firmicutes & Bacillus cereus biovar toyoi CNCM I-1012 (AJ310100) & 100 & + & bege & Rod & + & + \\
\hline LR 2-6 & KP407100 & Firmicutes & Bacillus cereus biovar toyoi CNCM I-1012 (AJ310100) & 100 & + & white & Rod & + & + \\
\hline LR 2-9 & KP407101 & $\gamma$-Proteobacteria & Pseudomonas punonensis LMT03 (JQ344321) & 98 & - & yellow & Rod & + & + \\
\hline LR 2-10 & KP407102 & $\beta$-Proteobacteria & Variovorax boronicumulans BAM-48 (AB300597) & 100 & - & yellow & Rod & - & + \\
\hline LR 2-11 & KP407103 & Firmicutes & Paenibacillus kribbensis AM49 (AF391123) & 99 & + & white & Rod & + & - \\
\hline LR 3-1 & KP407104 & $\gamma$-Proteobacteria & Pseudomonas frederiksbergensis JAJ28 (AJ249382) & 100 & - & yellow & Rod & + & + \\
\hline LR 3-2 & KP407105 & $\gamma$-Proteobacteria & Pseudomonas fuscovaginae ICMP 5940 (FJ483519) & 99 & + & bege & Rod & + & + \\
\hline LR 3-3 & KP407106 & Firmicutes & Bacillus cereus biovar toyoi CNCM I-1012 (AJ310100) & 100 & + & white & Rod & + & + \\
\hline LR 3-6 & KP407107 & $\gamma$-Proteobacteria & Pseudomonas fuscovaginae ICMP 5940 (FJ483519) & 99 & - & bege & Rod & + & + \\
\hline LR 3-7 & KP407108 & Firmicutes & Bacillus cereus ATCC 14579 (AE016877) & 100 & + & white & Rod & + & + \\
\hline LR 3-8 & KP407109 & Firmicutes & Bacillus aerophilus 28K (AJ831844) & 100 & + & bege & Rod & + & - \\
\hline LR 3-9 & KP407110 & Firmicutes & Bacillus drentensis LMG 21831 (AJ542506) & 99 & + & bege & Rod & + & + \\
\hline LR 3-10 & KP407111 & $\gamma$-Proteobacteria & Pseudomonas frederiksbergensis JAJ28 (AJ249382) & 99 & - & yellow & Rod & + & + \\
\hline LR 3-11 & KP407112 & $\alpha$-Proteobacteria & Rhizobium grahamii CCGE 502 (JF424608) & 99 & - & bege & Rod & + & + \\
\hline LS 1-1 & KP407113 & $\gamma$-Proteobacteria & Pseudomonas graminis DSM 11363 (Y11150) & 100 & - & yellow & Rod & + & - \\
\hline LS 1-2 & KP407114 & Firmicutes & Bacillus aryabhattai B8W22 (EF114313) & 100 & + & bege & Rod & + & + \\
\hline LS 1-4 & KP407115 & Firmicutes & Bacillus cereus biovar toyoi CNCM I-1012 (AJ310100) & 100 & + & bege & Rod & + & + \\
\hline LS 1-5 & KP407116 & $\gamma$-Proteobacteria & Pseudomonas graminis DSM 11363 (Y11150) & 100 & - & yellow & Rod & + & - \\
\hline LS 2-1 & KP407117 & $\gamma$-Proteobacteria & Pseudomonas congelans DSM 14939 (AJ492828) & 99 & - & bege & Rod & + & + \\
\hline LS 2-2 & KP407118 & $\gamma$-Proteobacteria & Pseudomonas graminis DSM 11363 (Y11150) & 100 & - & yellow & Rod & + & - \\
\hline LS 2-3 & KP407119 & $\gamma$-Proteobacteria & Pseudomonas lutea $\mathrm{OK} 2$ (AY364537) & 100 & - & yellow & Rod & + & - \\
\hline LS 3-1 & KP407120 & Firmicutes & Bacillus cereus biovar toyoi CNCM I-1012 (AJ310100) & 99 & + & bege & Rod & + & + \\
\hline LS 3-2 & KP407121 & $\gamma$-Proteobacteria & Pseudomonas lutea $\mathrm{OK} 2$ (AY364537) & 100 & - & yellow & Rod & + & - \\
\hline LS 3-5 & KP407122 & $\gamma$-Proteobacteria & Pseudomonas koreensis $\mathrm{Ps}$ 9-14 (AF468452) & 98 & - & bege & Rod & + & - \\
\hline LS 3-8 & KP407123 & $\gamma$-Proteobacteria & Xanthomonas vesicatoria ATCC 35937 (Y10761) & 100 & - & yellow & Rod & + & + \\
\hline
\end{tabular}


Table 2 - Characterization of bacterial endophytes for multiple plant growth promoting (PGP) traits: $\mathrm{NH}_{3}$, siderophore, IAA, $\mathrm{HCN}$ and extracellular enzymes: cellulase, pectinase, protease and lipase production and phosphate solubilization ability.

\begin{tabular}{|c|c|c|c|c|c|c|c|c|c|c|c|c|}
\hline \multirow{3}{*}{ Strain } & \multirow{3}{*}{ Closest relatives } & \multirow{3}{*}{$\mathrm{NH}_{3}$} & \multirow{3}{*}{ Siderophores } & \multirow{3}{*}{ P solubilization } & \multirow{3}{*}{ IAA $\left(\mathrm{mg} \mathrm{I}^{-1}\right)$} & \multirow{3}{*}{ HCN } & \multicolumn{6}{|c|}{ Extracellular enzymes } \\
\hline & & & & & & & \multirow{2}{*}{ Cellulase } & \multirow{2}{*}{ Pectinase } & \multirow[b]{2}{*}{ Protease } & \multicolumn{3}{|c|}{ Lipase } \\
\hline & & & & & & & & & & T20 & T40 & T80 \\
\hline $\begin{array}{l}\text { LR 1-1 } \\
\text { n }\end{array}$ & $\begin{array}{l}\text { Pseudomonas brassicacearum subsp } \\
\text { neoaurantiaca }\end{array}$ & + & + & + & $20.1 \pm 1.84$ & + & - & - & - & - & - & - \\
\hline LR 1-2 & Rhizobium nepotum & + & + & - & $27.8 \pm 2.22$ & + & - & - & - & - & - & - \\
\hline LR 1-5 & Pseudomonas moorei & + & +++ & + & $46.8 \pm 3.39$ & ++ & - & - & - & - & + & - \\
\hline LR 1-6B & Variovorax boronicumulans & + & + & - & $60.5 \pm 4.19$ & - & + & - & - & + & + & + \\
\hline LR 1-7 & Variovorax soli & + & + & + & $23.1 \pm 1.73$ & - & - & - & - & + & - & + \\
\hline LR 1-9 & Pseudomonas graminis & + & + & - & $51.4 \pm 3.58$ & + & - & + & - & + & - & - \\
\hline LR 1-11 & Bacillus cereus biovar toyoi & + & + & - & $25.8 \pm 2.99$ & ++ & + & + & ++ & + & + & + \\
\hline LR 1-12 & Caulobacter vibrioides & + & + & - & $34.1 \pm 1.82$ & + & + & + & ++ & + & - & - \\
\hline LR 1-13 & Variovorax boronicumulans & + & + & - & $40.2 \pm 3.66$ & + & - & - & - & + & + & + \\
\hline LR 1-16 & $\begin{array}{l}\text { Pseudomonas brassicacearum subsp } \\
\text { neoaurantiaca }\end{array}$ & + & + & - & $33.4 \pm 2.52$ & ++ & - & - & - & + & - & - \\
\hline LR 2-1 & Bacillus thuringiensis & + & + & - & $6.3 \pm 0.47$ & ++ & - & - & ++ & + & + & + \\
\hline LR 2-2 & Pseudomonas kilonensis & + & +++ & - & $26.0 \pm 2.26$ & ++ & - & - & ++ & + & - & + \\
\hline LR 2-3 & Pseudomonas jessenii & + & +++ & - & $17.4 \pm 2.55$ & ++ & - & - & ++ & + & - & + \\
\hline LR 2-4 & Bacillus cereus biovar toyoi & + & + & - & $25.5 \pm 0.70$ & ++ & - & - & + & + & + & + \\
\hline LR 2-6 & Bacillus cereus biovar toyoi & + & +++ & - & $7.3 \pm 1.27$ & ++ & + & - & ++ & + & + & - \\
\hline LR 2-9 & Pseudomonas punonensis & + & + & - & $9.8 \pm 1.10$ & ++ & + & + & ++ & + & + & + \\
\hline LR 2-10 & Variovorax boronicumulans & + & + & - & $11.7 \pm 1.26$ & ++ & - & + & ++ & + & + & + \\
\hline LR 2-11 & Paenibacillus kribbensis & - & + & - & $7.3 \pm 1.43$ & ++ & + & + & ++ & + & + & - \\
\hline LR 3-1 & Pseudomonas frederiksbergensis & + & + & + & $8.9 \pm 0.55$ & ++ & + & ++ & ++ & + & - & + \\
\hline LR 3-2 & Pseudomonas fuscovaginae & + & + & + & $21.2 \pm 1.87$ & ++ & + & ++ & + & + & - & - \\
\hline LR 3-3 & Bacillus cereus biovar toyoi & + & +++ & - & $10.2 \pm 0.64$ & ++ & + & + & ++ & + & + & + \\
\hline LR 3-6 & Pseudomonas fuscovaginae & + & ++ & - & $8.3 \pm 1.41$ & ++ & + & + & ++ & - & - & - \\
\hline LR 3-7 & Bacillus cereus & + & +++ & + & $7.4 \pm 1.17$ & +++ & - & + & ++ & + & + & - \\
\hline LR 3-8 & Bacillus aerophilus & + & + & + & $10.2 \pm 1.37$ & + & + & + & ++ & + & + & + \\
\hline LR 3-9 & Bacillus drentensis & + & + & + & $10.2 \pm 1.18$ & ++ & + & + & ++ & - & - & - \\
\hline LR 3-10 & Pseudomonas frederiksbergensis & + & + & + & $35.4 \pm 3.95$ & ++ & - & + & ++ & + & - & + \\
\hline LR 3-11 & Rhizobium grahamii & + & + & - & $7.0 \pm 0.50$ & ++ & - & + & ++ & + & + & - \\
\hline LS 1-1 & Pseudomonas graminis & + & + & + & $66.3 \pm 8.56$ & + & + & + & ++ & - & + & - \\
\hline LS 1-2 & Bacillus aryabhattai & + & + & + & $18.4 \pm 1.48$ & +++ & + & + & ++ & - & - & - \\
\hline LS 1-4 & Bacillus cereus biovar toyoi & + & + & - & $19.2 \pm 1.36$ & ++ & - & + & ++ & + & + & + \\
\hline LS 1-5 & Pseudomonas graminis & + & + & + & $14.1 \pm 2.42$ & ++ & + & + & ++ & - & + & - \\
\hline LS 2-1 & Pseudomonas congelans & + & + & - & $74.7 \pm 8.20$ & ++ & + & + & ++ & + & - & - \\
\hline LS 2-2 & Pseudomonas graminis & + & + & - & $47.9 \pm 3.64$ & ++ & + & + & ++ & + & + & - \\
\hline LS 2-3 & Pseudomonas lutea & + & +++ & + & $45.7 \pm 3.57$ & ++ & + & + & ++ & - & + & - \\
\hline LS 3-1 & Bacillus cereus biovar toyoi & + & + & - & $9.7 \pm 1.80$ & +++ & - & + & ++ & + & + & + \\
\hline LS 3-2 & Pseudomonas lutea & + & + & + & $17.5 \pm 1.94$ & ++ & + & + & ++ & - & - & - \\
\hline LS 3-5 & Pseudomonas koreensis & + & + & - & $8.7 \pm 1.13$ & ++ & - & + & ++ & + & - & - \\
\hline LS 3-8 & Xanthomonas vesicatoria & + & + & - & $18.8 \pm 1.50$ & + & - & ++ & ++ & + & + & + \\
\hline
\end{tabular}

IAA is expressed as means $\pm \mathrm{SE}(\mathrm{n}=5$ to 12$)$. $(-)$ negative, $(+)$ positive/weak, $(++)$ intermediate, $(+++)$ strong production. 


\section{Fig. 1}

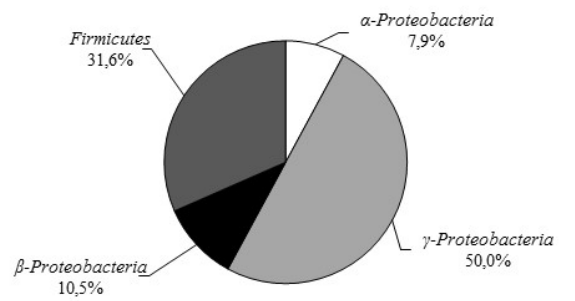

LS 2-2 (KP407118)

LS 2-3 (KP407119)

99 LS 1-5 (KP407116)

99 LS 1-1 (KP407113)

52 Pseudomonas lutea (AY364537.1)

2 Pseudomonas graminis (Y11150.1)

$10,5 \%$

52 LS 3-2 (KP407121)

52 LR 1-9 (KP407091)

LR 3-2 (KP407105)

43 LR 3-6 (KP407107)

90 LS 3-5 (KP407122)

10. Pseudomonas fuscovaginae (FJ483519.1)

| Pseudomonas moorei (AM293566.1)

62 Pseudomonas jessenii (AF068259.1)

95 LR 1-5 (KP407088)

LR 2-3 (KP407098)

[ Pseudomonas punonensis (JQ344321.1)

58 LR 2-9 (KP407101)

81 Pseudomonas congelans (AJ492828.1)

58 LS 2-1 (KP407117)

34 Pseudomonas tremae (AJ492826.1)

Pseudomonas kilonensis (AJ292426.1)

96 LR 2-2 (KP407097)

49 ILR 3-1 (KP407104)

89 LR 3-10 (KP407111)

60 [ Pseudomonas brassicacearum subsp. neoaurantiaca (EU391388.2)

67 Pseudomonas frederiksbergensis (AJ249382.1)

${ }_{60}$ LR 1-1 (KP407086)

LR 1-16 (KP407095)

100 Xanthomonas vesicatoria $(\mathrm{Y} 10761.1)$

LS 3-8 (KP407123)

98 Variovorax soli (DQ432053.1)

LR 1-7 (KP407090)

100 [ Variovorax boronicumulans (AB300597.1)

93 LR 1-13 (KP407094)

${ }_{66}$ LR 1-6B (KP407089)

${ }_{66} 6{ }_{\text {LR } 2-10(\text { KP407102) }}^{\text {LR } 1-6 B(K P 40708) ~}$

$\begin{array}{cc}100 & \text { Caulobacter vibrioides (AJ009957.1) } \\ \text { LR 1-12 (KP407093) } & 100 \text { Rhizobium sp. (FR870231.1) }\end{array}$

$\begin{array}{cc}100 & \text { Caulobacter vibrioides (A. } \\ \text { LR 1-12(KP407093) } \\ 198 \quad 100[\text { Rhizobium sp. (FR870231.1) }\end{array}$

$98 \quad 100\left[\begin{array}{l}\text { Rhizobium sp. (FR8 } \\ \text { LR 1-2 (KP407087) }\end{array}\right.$

$98 \quad$ Rhizobium grahamii (JF424608.1)

100 LR 3-11 (KP407112)

\begin{tabular}{|l|l|l|}
100 & Paenibacillus kribbensis (AF391123.1) \\
LR 2-11 (KP407103) & 100 Bacillus drentensis (AJ542506.1)
\end{tabular}

\begin{tabular}{|l|l|l|l|l|}
100 & Paenibacillus kribbensis (AF391 \\
LR 2-11 (KP407103) \\
100
\end{tabular}

99

LR 3-9 (KP407110)

$99 \quad 100$ Bacillus aryabhattai (EF114313.2)

25 \begin{tabular}{r|l} 
LS 1-2 (KP407114) \\
100
\end{tabular}

100 LR 3-8 (KP407109)

LR 3-7 (KP407108)

${ }_{46} \quad$ LS 1-4 (KP407115)

64 LR 3-3 (KP407106)

Bacillus thuringiensis (D16281.1)

Bacillus cereus biovar toyoi (AJ310100.1)

100 LR 1-11 (KP407092)

LR 2-1 (KP407096)

${ }_{64}$ LR 2-4 (KP407099)

64 LR 2-6 (KP407100)

LS 3-1 (KP407120) 